\title{
The Contribution of Eye and Hand Coordination to Under Passing Volleyball of Extracurricular Students SMP Negeri 4 Pekanbaru
}

\author{
Sasmarianto \\ University Islamic of Riau \\ Pekanbaru, Indonesia \\ sasmarianto@edu.uir.ac.id
}

\begin{abstract}
Based on the writer's observation in the field shows that the ability of under passing students extracurricular SMP Negeri 4 Pekanbaru still low. This study aims to determine whether there is a contribution of eye and hand coordination of under passing the volleyball of extracurricular students SMP Negeri 4 Pekanbaru. Research method is a correlation method. The total population in this study amounted to 15 male students using total sampling technique. The population is sampled so that the number of sample in this study is $\mathbf{1 5}$ extracurricular students SMP Negeri 4 Pekanbaru. Based on the calculation of product moment's correlation is obtained $r$ value (correlation index) variable $x$ and variable $y$ or $\mathbf{r x y}$ value. Great value $\mathbf{r x y}=\mathbf{0 . 5 3 8}$. The $r$ value of the table at $n=15$ or $\mathrm{df}=13$ is 0.514 . The result of comparison or between $r$ arithmetic and $r$ table found that the value of $r h>r$ t or $0.538>0,514$. Because the value of $r$ count is greater than the value of $r$ table then there is a contribution between the two variables. Thus the hypothesis is that there is a contribution of eye and hand coordination with under passing ability the volleyball of extracurricular students SMP Negeri 4 Pekanbaru and it is acceptable. Based on data analysis and discussion it can be concluded that there is contribution of eye and hand coordination to under passing's volleyball of extracurricular students SMP Negeri 4 Pekanbaru at 28, $9 \%$.
\end{abstract}

Keywords-volleyball, contribution of eye and hand, and coordination

\section{INTRODUCTION}

Sport is an investment in the future. Through the exercise, human beings will be healthy and fit so that the mental and character can be built. As the proverb in the world of sports says "Men Sanna in corporesanno" which means"within a healthy body there is a strong soul "has a very deep meaning, that the health of the body has a very strong influence towards the development of the soul. In this situation, the sport is supposed to be a pillar ofconformity, healthy life and harmonious balance. Sport is able to form the souls and characters. The soul of fairplay, sportsmanship, team work and uphold nationalism can be built through sports. But the next issue is how strategic efforts to develop the sport in the development of the character so that at the end of the sport becomes more valuable and efficient. This is not an easy job for a developer of sports in order to optimize the character building such as in Indonesia that is multi characters.
Onemethod is by introducing sports from the level of formal education or school. The sport is introduced from basic education up to high school. In schools, sport is one of the compulsory subjects.

As stated in the Constitution of the Republic of Indonesia No. 3 year 2005 article 1 and 2 which reads (1) sports the education is organized as part of the education process. And (2) sports education is implemented at both the formal and non-formal education path through intracurricularand/or extracurricular activities.

From the above articles can be explained that in education, the existence of the sport cannot be separated. This is because to achieve the accomplishment in the world of education requires a healthy body and soul. It can be done by keeping the health and exercise. In these subjects, the students are taught various sports, and one of them is a volleyball. Aside from the subject, volleyballis also interestingto students inextracurricular activities.

The volleyball is a team game with a total squad of six people on its team. The volleyball is one of the sports that is played by volleying the ball over the net, with the aim and purpose to drop the ball into the opponent's side of the court to seek victory in the play.

The basic technique is one of the main factorthat can measure the level of proficiency in playing volleyball, in addition the factors of physical condition, players' mental and strategy formulation. Therefore, each player is obliged to know the basic technique and learn it. If in a team all the players have a good basic technique, it can be ascertained that the team has the strength and quality of a good team.

One technique is oftenused in the volleyball is under passing. Under passing in the volleyball is the foundation that must be mastered by every player. Under passinghassome functions to restore services, give feedback, and passing the ball to the opponent's side of the court. Under passing is a step to take the ball by using two arms that are combined and hit on a little above of the wrist.

Under passingshould be done with either appropriately good direction or height. Under passing will be forwarded to feed to the other players. In order to perform a goodunder passing, a player should train regularly, besides technical and physical training should be also undertaken. There are several 
physical conditions that affect the ability of under passing in volleyball game and one of them is the coordination of eye and hand.

Coordination is a person's biomotorability to perform the sequence of movement properly, correctly and accurately without experiencing interference. When is briefly engaged with the eyes and hands, can be interpreted as the ability of doing hand gestures when doing the movements of objects in order to move right to the target seen by the eye.

Based on the results of observation that the researcher did on extracurricular students SMP Negeri 4 Pekanbaru when they practiced volleyball, researcher found few problems related to the capability of under passing, among others, as followed: when doing the under passing, swing too hard that balls go wild that it is related to the rhythm of the incorrectly under passing movement, under passing which is not accurate in the direction or the height that it is related with the eye and hand's coordination of students. Students often are not ready to accept the ball that it is related to the speed of students' reaction. The results of under passing are sometimes too fast that it is related to the strength of the students' arms muscles that is less controllable.

Based on the results of that observation, researcher is interested in holding a final assignment as a research student. The title of the research to be raised is the contribution of the eye and hand's coordination of under passing the volleyball of the extracurricular students SMP Negeri 4 Pekanbaru.

\section{MATERIALS AND METHODS}

The type of research is correlation method. The variable $\mathrm{X}$ in this research is the coordination of eye and hand and the variable $\mathrm{Y}$ is the ability of volleyball'sunder passing.

Researcher takes extracurricular students of SMP Negeri 4 Pekanbaru to serve as the research population. The number of students extracurricular SMP Negeri 4 Pekanbaru are 15 male students. In this researchis devoted only on the male students for the homogenous research as the number of male student population is not too many then the researcher uses the technique of total sampling or the whole population is used as samples. Therefore the number of the sample in this research is 15 extracurricular students of SMP Negeri 4 Pekanbaru

\section{RESULTS AND DISCUSSION}

Researcher did aresearch on the volleyball court in SMP Negeri 4 Pekanbaru. In line with the number of variables the research which amount 2 pieces, researcher conducted two types of tests. The first test that is a tennis ball-throwing test to measure eye and hand coordination and a under passingtest to determine the students' under passing volleyball ability.

From the results of data above can be explained that the coordination of eye and hand are known to contribute to the ability of volleyball's under passing. To perform a good under passing, a player must be able to direct the ball with the direction and height as aimed. This requires that a volleyball player has a good degree of accuracy. The level of accuracy relates to the coordination of eye and hand of the player.
With good eye and hand accuracy, theplayer can move his hand to dounder passingof the volleyball and direct the ball to the aimed target or to the partner. Thus the ball of the under passing can be precisely up to the intended recipients with accurate direction or height.

From the results of this research, the contribution of the eye and hand's ability of under passing is $28.9 \%$. The percentage means each perform of under passing, $28.9 \%$ of those passing success is influenced by the level of coordination of eye and hand of the player. Other supporting factors in volleyball under passing of $71.1 \%$ are influenced by other supporting factors besides the coordination of eye and hand.

These factors include passing basic techniques, the strength and balance of the arm muscles. Passing basic techniques are efficient to perform a series of motion basic techniques to well under passing. The next factor is the factor of arm muscle's strength, it is used to hold the speed of the ball to be reflected back towards the aim. Strength of the arm muscles according to Wiarto (2013:17) is the ability of a muscle to do the contractions that are efficient to evoke the tension on a resistance. This is useful to hold the ball that glides so that the ball is able to bounce towards the aim.

A balance factor is useful to keep the body stable when taking the ball with under passing. The balance factor is also required so that the player can receive the ball without falling, so it can perform advanced motion when necessary. Ismaryati (2008:48) "balance is the ability to maintain the balance in a state of still or moving.

In addition to these factors, the speed of reaction in taking the ball with the technique of under passing is also a factor that affects the ability of volleyball under passing. The speed of reaction according to Ismaryati (2008:72) reaction time is the period between the stimuli received by the beginning of a reaction or response. All information that is received by the sense both from inside and outside is called stimuli. Sense will change the information into nerve impulses and can be understood by the brain. In volleyball, the stimuli appears from the arrival of the ball towards the player, and the response is set upunder passing technique as quickly as possible to fend the ball that came.

\section{CONCLUSION}

Based on data analysis and discussion, it can be concluded that there is conclusion of the contributionthe eye and hand's coordination against under passing of the volleyball extracurricular student SMP Negeri 4 Pekanbaru $28.9 \%$. Comparison of results obtained that the value $r(0.538)>r$ table (0.514).

\section{REFERENCES}

[1] CDC, "Guideline for Evaluating Insecticide Resistance in Vectors Using the CDC Bottle Bioassay", CDC Methods, 2012, p. 1-28.

[2] N. Ahmadi, Panduan Olahraga Bola Voli, Era Pustaka Utama, 2007.

[3] D. Beutelstahl, Belajar bermain Bola Volley, Pionir Jaya, 2008.

[4] Ma'mun, Anang and T. Subroto, Pendekatan Keterampilan Taktis dalam Pembelajaran Bola voli Konsep dan Metode Pembelajaran. Jakarta: Direktorat Jendral Olahraga, 2001. 
[5] A. Sudijono, Pengantar Statistik Pendidikan, Rajawali Press, 2009.

[6] Sugiyono, Metode Penelitian Pendidikan Pendekatan kuantitatif, kulatitatif, dan R\&D, Bandung: Alfabeta, 2009.

[7] J. Tangkudung, Pembinaan Prestasi Olahraga. Jakarta: Cerdas Jaya, 2006.
[8] Viera, Barbara.L and B.J Fergusson, .Bola voli Tingkat Pemula.Jakarta: Raja GrafindoPersada, 2004.

[9] Winarno, TesKeterampilanOlahraga. Malang : UNM, 2006. 